\title{
Postulaty polityczne szlachty województwa mazowieckiego na sejmikach poselskich przed konwokacją 1733 roku
}

\begin{abstract}
Abstrakt: Artykuł poświęcono sejmikom przedsejmowym w województwie mazowieckim w okresie przedostatniego bezkrólewia w Rzeczypospolitej. Szczególną uwagę skupiono na przedstawieniu głównych postulatów i hasłeł zawartych w instrukcjach poselskich.

Słowa kluczowe: Stanisław Leszczyński, województwo mazowieckie, sejmiki przedkonwokacyjne, bezkrólewie w 1733 roku
\end{abstract}

Problematyka postulatów politycznych szlachty województwa mazowieckiego na sejmikach poselskich przed przedostatnią konwokacją ${ }^{1}$ - jak do tej pory - nie wzbudziła szczególnego zainteresowania historyków. Ogólnie pisali o tym zagadnieniu Szymon Askenazy, Henryk Olszewski i Józef Andrzej Gierowski². W niniejszym artykule poddano analizie dziesięć sejmików: czerski, warszawski, wyszogrodzki, zakroczymski, ciechanowski, wiski, łomżyński, różański, nurski i liwski, które funkcjonowały w województwie mazowieckim ${ }^{3}$. Skupiono się przede wszystkim na postulatach politycznych związanych z wyborem kandydata na nowego króla po zgonie Augusta II i sposobie zabezpieczenia przedostatniego bezkrólewia, w niewielkim zaś stopniu na sprawach poruszających kwestie gospodarcze, które wymagają osobnych badań. Podstawową bazą źródłową są zachowane lauda i instrukcje

1 J.A. Gierowski: Sejmik generalny Księstwa Mazowieckiego. Wrocław 1948, s. 25.

2 S. Askenazy: Przedostatnie bezkrólewie. W: Idem: Dwa stulecia XVIII i XIX. Badania i przyczynki. T. 1. Warszawa 1901, s. 1-174; H. Olszewski: Doktryny prawno-ustrojowe czasów saskich (1697-1740). Warszawa 1961, s. 231-254; J.A. Gierowski: Sejmik..., s. 14-94.

${ }^{3} \mathrm{~W}$ skład powyższych ziem wchodziło 27 powiatów, zob. A. PAw Í́ski: Polska XVI wieku pod względem geograficzno-statystycznym. T. 5: Źródła dziejowe. T. 16. Warszawa 1895, s. 1-3. 
sejmikowe, w tym liczne odpisy sporządzone przez Adolfa Pawińskiego znajdujące się w Tekach Pawińskiego. Stosunkowo ciekawe materiały udało się znaleźć w Archiwum Głównym Akt Dawnych w Warszawie oraz w Bibliotece Książąt Czartoryskich w Krakowie.

Niewątpliwie duży wpływ zarówno na przebieg rozpoczętych 11 marca 1733 roku obrad sejmików przedkonwokacyjnych w województwie mazowieckim, jak i na zakres poruszanych na nich spraw wywarły uniwersały i listy rozsyłane przez czołowych stronników Stanisława Leszczyńskiego: interrexa - prymasa Teodora Potockiego ${ }^{4}$ i wojewodę mazowieckiego Stanisława Poniatowskiego ${ }^{5}$. Zachęcano w nich szlachtę do zgody i jedności, wskazując na zewnętrzne zagrożenie Rzeczypospolitej ze strony państw ościennych ${ }^{6}$. Ważną rolę w przedsejmowej kampanii propagandowej odegrały także pisma ulotne, w szczególności „Promovenda na sejmikach antykonwokacyalnych". Wymierzone ono było przeciwko kandydaturze do tronu elektora saskiego Fryderyka Augusta II i sugerowało wybór „Piasta”. Niewątpliwie chodziło tu o Stanisława Leszczyńskiego, chociaż konkretnego nazwiska nie wskazywano. Sugestia ta znalazła wyraźne odbicie w laudach i instrukcjach poselskich województwa mazowieckiego ${ }^{7}$.

${ }^{4}$ S. Askenazy: Przedostatnie bezkrólewie..., s. 71; K. Maliszewski: Szlachecka opinia publiczna wobec powtórnej elekcji Stanisława Leszczyńskiego w 1733 r. Próba zarysowania problemu w świetle ówczesnej prasy rękopiśmiennej. „Rocznik Gdański” 1986, 46, z. 1, s. 75.

${ }^{5}$ Stanisław Poniatowski uważany był także za jednego z kandydatów do tronu polskiego, cieszył się on dużym poparciem wśród szlachty. Do obozu stanisławowskiego, jak twierdził V.J. Gerje, został pozyskany przez prymasa Teodora Potockiego kwotą 20 tys. czerwonych złotych. Jako wojewoda mazowiecki, podobnie jak inni wojewodowie, miał znaczny wpływ na kształtowanie się opinii publicznej. Niewątpliwie działania te były jednak kosztowne, stąd zaciągnięte przez niego pożyczki, które miały być większe niż jego majątek. Haus-, Hof- Und Staatsarchiv w Wiedniu (dalej: HHStA Wien), Polen II 8, k. 213, List H.W. Wilczka do Karola VI, Warszawa 6 IV 1733; Archiwum Główne Akt Dawnych (dalej: AGAD), Archiwum Zamoyskich (dalej: AZ), rkps 2878, k. 15, Manifest przedsejmowy regimentarza koronnego Stanisława Poniatowskiego, Solec 3 III 1733; AGAD, Archiwum Radziwiłłów (dalej: AR), dz. V, rkps 8541, k. 33, List J. Lipskiego do NN, Warszawa 16 II 1733. Zob. inne postulaty: Biblioteka Książąt Czartoryskich (dalej: BCzart.), Muzeum Narodowe w Krakowie (dalej: MNK), rkps 50, k. 173, List marszałka nadwornego Franciszka Bielińskiego, na sejmik warszawski, [b.m.] 5 III 1733; V.J. GerJe: Borba za Pol'skij prestoł $v 1733$ godu. Moskva 1862, s. 146; S. Askenazy: Przedostatnie bezkrólewie..., s. 108; K. KantecKI: Stanisław Poniatowski, kasztelan krakowski ojciec Stanisława Augusta. T. 2. Poznań 1880, s. 174; M. Matuszewicz: Diariusz życia mego. T. 1: 1714-1757. Oprac. B. Królıkowski. Warszawa 1986, s. 47; P. Boyé: Stanislaw Leszczynski et le troisième traité de Vienne. Paris 1898, s. 119.

${ }^{6}$ BCzart., MNK, rkps 32, k. 34, Uniwersał prymasa Teodora Potockiego na sejmiki przedkonwokacyjne do województw, [b.m. i b.d.] 1733; ibidem, rkps 50, k. 46, List Stanisława Poniatowskiego, regimentarza generalnego koronnego na sejmiki przedsejmowe, Solec 3 III 1733; Biblioteka Zakładu Narodowego im. Ossolińskich we Wrocławiu (dalej: BOssol.), rkps 302, k. 108, List od wojewody mazowieckiego regimentarza generalnego koronnego na sejmiki, Solec 3 III 1733.

${ }^{7}$ H. Olszewski: Doktryny..., s. 230-231. 
Pierwszy z sejmików mazowieckich, sejmik ziemi czerskiej, rozpoczął obrady w Czersku, marszałkował mu pisarz ziemski czerski Antoni Karczewski ${ }^{8}$. Na sejmiku wybrano sędziów kapturowych, wśród nich gorliwego stronnika Stanisława Leszczyńskiego - kasztelana czerskiego Kazimierza Rudzińskiego. Łącznie wybrano 25 osób ${ }^{9}$. Kasztelan czerski został także wybrany na pułkownika całej ziemi czerskiej i powiatu. Rotmistrzami zaś zostali: z powiatu grójeckiego - Adam Tarło, starosta goszczyński, garwolińskiego - Franciszek Rudziński, starosta kruszwicki (obydwaj to elektorowie Leszczyńskiego) ${ }^{10}$, wareckiego - Paweł Boski, starosta stromiecki. Natomiast funkcję strażnika i chorążego powierzono podczaszemu kijowskiemu Adamowi Oczosalskiemu i chorążemu latyczewskiemu Wojciechowi Magnuszewskiemu. Na sejmiku wybrano także dwóch posłów z ziemi czerskiej na sejm konwokacyjny - mandaty poselskie otrzymali starosta kruszwicki Franciszek Rudziński i podstoli czerski Kasper Suffczyński ${ }^{11}$. Skądinąd wybrano także posłów do prymasa T. Potockiego: sędziego kapturowego Zygmunta Staniszewskiego i starostę stromieckiego Pawła Boskiego ${ }^{12}$.

Zebrana w Czersku szlachta opowiedziała się zdecydowanie trwać przy świętej wierze katolickiej rzymskiej, dawnych swobodach i wolnościach. W laudum wyraźnie sprzeciwiono się przekształceniu sejmu konwokacyjnego w sejm elekcyjny, który miał "nastąpić” przez pospolite ruszenie całej Rzeczypospolitej ${ }^{13}$. Tym samym zalecano posłom promowanie na tron polski wśród innych posłów kandydatury króla katolika i Polaka. Podobnie jak na innych sejmikach województwa mazowieckiego, także na sejmiku czerskim ujawniły się silne tendencje ksenofobiczne, an-

8 J.A. Gierowski: Sejmik..., s. 36.

9 Biblioteka Naukowa Polskiej Akadmii Umiejętności i Polskiej Akademii Nauk w Krakowie (dalej: BPAU i PAN), Teki Pawińskiego (dalej: TP), rkps 8320, k. 259v, Laudum sejmiku przedsejmowego czerskiego, 11 III 1733.

10 Franciszek Rudziński, starosta kruszwicki, był synem kasztelana czerskiego Kazimierza Rudzińskiego, ożeniony z Teresą z Tarłów, co dawało mu wsparcie Tarłów, czołowego rodu małopolskiego, w tym Jana Tarły, wojewody lubelskiego, lidera obozu stanisławowskiego w okresie przedostatniego bezkrólewia. W. Rudzıński: Franciszek Rudziński. W: Polski słownik biograficzny. T. 33. Wrocław 1991, s. 17; M. Matuszewicz: Diariusz..., s. 49.

11 Kasper Suffczyński, podstoli czerski, zaliczany był do klienteli wojewody ruskiego Augusta Czartoryskiego. Zob. Z Warszawy d. 12 Martii 1733. W: Od Augusta Mocnego do Augusta III. Doniesienia $z$ Warszawy Andrzeja Cichockiego z lat 1732-1734. Wyd. J. DygdaŁA. Warszawa 2016, s. 221; E. SzKLARSKA: Kwestia wykluczenia cudzoziemca od tronu na sejmie konwokacyjnym 1733 r. W: Między Zachodem a Wschodem. Studia ku czci profesora Jacka Staszewskiego. T. 2. Red. J. DuMANOWSKI. Toruń 2003, s. 563-565.

12 Pod od koniec marca posłowie czerscy wydelegowani na sejm konwokacyjny mieli się spotkać z prymasem, zabiegając o wypłacenie przez królewicza Fryderyka Augusta II długów swego ojca zaciągniętych m.in. u Jakuba Sobieskiego na kwotę 900 tys. talarów, Z Warszawy d. 28 Martii $1733 . . .$, s. 230.

13 BPAU i PAN, TP, rkps 8320, k. 266v, Oblata laudum sejmiku przedsejmowego, Czersk 11 III 1733. 
tydysydenckie, tak charakterystyczne dla obozu narodowego. Stąd m.in. tak bardzo popularne hasła żądające usunięcia oficerów dysydenckich z regimentów zarówno koronnych, jak i Wielkiego Księstwa Litewskiego. Co więcej, szlachta wprost optowała, aby oficerami byli tylko katolicy, a komendy wydawano wyłącznie po polsku. Nieufność wobec ministrów cudzoziemskich, którzy mogli ingerować w przebieg elekcji, sprawiła, że domagano się ich usunięcia z Warszawy i z całej Rzeczypospolitej $^{14}$. Wnioskowano przy tym, aby wcześniejsze układy z państwami ościennymi były zachowane. Zgadzano się na aukcję wojska, które opłacane miało być m.in. z podatków z dóbr kościelnych i żydowskich, oraz na rewizję kwarty po wszystkich starostwach dziedzicznych i dobrach królewskich. Wobec narastającego zagrożenia zewnętrznego szlachta czerska opowiedziała się za integralnością państwa, podkreślając konieczność utrzymania całości Rzeczypospolitej, stąd hasła zachowania Kurlandii, powiatu piltyńskiego, starostwa drahimskiego i miasta Elbląga.

W laudum podano, że szlachta potępiła jednoznacznie zawiązaną bez zgody prymasa T. Potockiego wcześniejszą konfederację w województwie krakowskim ${ }^{15}$. Twierdzono, że jest ona wbrew prawu i podważa władzę prymasa ${ }^{16}$. W laudum pojawiły się też żądania zwrotu przez królewicza Fryderyka Augusta II wszystkich wywiezionych do Saksonii rzeczy oraz spłaty długów pozostawionych po śmierci króla Augusta Mocnego $\mathrm{II}^{17}$. Generalnie rzecz biorąc, można powiedzieć, że sejmik, który zakończył obrady 12 marca 1733 roku, zdominowany został przez obóz stanisławowski ${ }^{18}$.

Przedstawiciele ziemi warszawskiej zebrali się w kościele św. Marcina w Warszawie. Obrady odbyły się przy dużej frekwencji szlachty. Na sejmiku byli także obecni senatorowie: Stanisław J. Hozjusz, biskup poznański, Antoni Potocki, wojewoda bełski, i Michał Czartoryski, podkanclerzy litewski ${ }^{19}$. Sejmik zagajał biskup

${ }^{14}$ Aneks: Relacja Löwenwolda, 8 marca 1733 r. W: V.I. GeRJE: Borba..., s. 72 . O niechęci wobec cudzoziemców w tym okresie donosił także poseł cesarski hrabia Henryk Wilhelm Wilczek, pisząc, $\dot{z ̇ e}$ „żaden cudzoziemiec ani chwili swego życia pewien być nie może [...]”. HHStA Wien, Polen II 8 , k. 212-214, List H.W. Wilczka do Karola VI, Warszawa 12 IV 1733.

${ }^{15}$ J. Dygda£A: Konfederacja krakowska Teodora Lubomirskiego z początków bezkrólewia 1733 roku a polityka Austrii wobec Rzeczypospolitej. W: Trudne stulecia. Studia z dziejów XVII i XVIII wieku, ofiarowane Profesorowi Jerzemu Michalskiemu w siedemdziesiąta rocznicę urodzin. Red. Ł. KąDZiela. Warszawa 1994, s. 48-49.

${ }_{16}$ BOssol., rkps 302/II, k. 78, List T. Potockiego do S. Poniatowskiego, Warszawa 25 II 1733.

17 BPAU i PAN, TP, rkps 8320, k. 265v, Oblata laudum sejmiku przedsejmowego, Czersk 11 III 1733.

${ }_{18}$ Do stronników Leszczyńskiego w ziemi czerskiej należy także zaliczyć starościca czerskiego Jana Rostworowskiego. K. MALIszewski: Szlachecka..., s. 74; BPAU i PAN, TP, rkps 8320, k. 264v, Laudum sejmiku przedsejmowego, Czersk 11 III 1733.

19 Zarówno Czartoryscy, jak i Potoccy opowiedzieli się w bezkrólewiu po stronie Piasta, zob. J. DygdaŁA: Saskie próby infiltracji środowisk szlacheckich podczas bezkrólewia 1733 roku. „Kwartalnik Historyczny" 2003, R. 110, z. 4, s. 52; S. Askenazy: Przedostatnie bezkrólewie..., s. 90. 
poznański S.J. Hozjusz (zwolennik Sasa) ${ }^{20}$, wysuwając na marszałka kandydaturę Kazimierza Potrykowskiego, chorążego różańskiego. Sprzeciwiła się temu część szlachty, przedstawiając jako kontrkandydata Stanisława Sobolewskiego, pisarza ziemskiego warszawskiego. Doprowadziło to do rozłamu sejmiku, w wyniku czego partia pisarza ziemskiego warszawskiego na znak protestu wyszła z kościoła. Ostatecznie doszło jednak ponownie do wspólnych obrad pod węzłem konfederacji, na której czele stanął pisarz ziemski S. Sobolewski ${ }^{21}$. Do boku jego wybrano łącznie 5 konsyliarzy. Sejmikująca szlachta dokonała także wyboru posłów na sejm konwokacyjny, którymi zostali Jan Mniszech, starosta jaworowski ${ }^{22}$, i Franciszek Kalisz, miecznik gostyński ${ }^{23}$. Wybrano również posłów do prymasa T. Potockiego i marszałka wielkiego koronnego J. Mniszcha, którymi zostali K. Petrykowski, chorąży różański, i Józef Skulski, regent marszałkowski² ${ }^{24}$ Również w trakcie wyborów sędziów do sądów kapturowych nie obyło się bez rywalizacji o tę funkcję, która często była narzędziem nacisku na szlachtę $e^{25}$. Marszałkiem sejmiku został obrany z ziemi warszawskiej Antoni Potocki, wojewoda bełski ${ }^{26}$. Łącznie wybrano 37 osób ${ }^{27}$. Następnie na sejmiku odczytano list prymasa T. Potockiego, sprzeciwiono się natomiast czytaniu listów Józefa Potockiego, wojewody kijowskiego, i Teodora Lubomirskiego, wojewody krakowskiego. Przeciw temu ostatniemu najbardziej protestowali wojewoda podolski Stefan Humiecki ${ }^{28}$ i S. Poniatowski, wojewoda

${ }^{20}$ J. Dygda£A: Episkopat rzymskokatolicki doby saskiej. Aktywność w życiu publicznym. W: Między monarcha a demokracja. Studia $z$ dziejów Polski XV-XVIII wieku. Red. A. SuchenI-GrabowsKa, M. ŻArYn. Warszawa 1994, s. 342.

${ }^{21}$ Zob. Z Warszawy d. 12 Martii 1733..., s. 223.

${ }^{22}$ Według posła angielskiego Georga Woodwarda miał być on nazywany „delicjami narodu”, zob. Rok 1733 w Polsce od śmierci Augusta II do elekcji Augusta III, podłóg raportów dyplomatycznych ajentów angielskich. „Przegląd Poznański” 1861, t. 32, z. 2, s. 122-123; Aneks: Relacja Löwenwolda, 2 marca 1733 r. W: V.I. GERJE: Borba..., s. 66.

${ }^{23}$ BPAU i PAN, TP, rkps 8345, k. 177, Laudum sejmiku przdkonwokacyjnego warszawskiego, Warszawa 11 III 1733.

${ }^{24}$ BCzart., MNK, rkps 32, k. 43v, Punkta instrukcji Panu Kazimierzowi Petrykowskiemu, chorążemu różańskiemu i Józefowi Skulskiemu, regentowi marszałkowskiemu koronnemu posłom do Józefa Mniszcha, marszałka wielkiego koronnego z sejmiku przedkonwokacyjnego warszawskiego, Warszawa 11 III 1733; ibidem, k. 44, Respons na punkta tej instrukcji, [b.m. i b.d.] 1733.

${ }^{25} \mathrm{~W}$ świetle doniesień gazety pisanej każdy powiat miał wybrać po sześć osób, w rzeczywistości liczba ta była nieco większa i zróżnicowana, np. w powiecie tarczyńskim wynosiła 11 osób, błońskim - 12 osób. „Kurier Polski” 1733, nr 169; AGAD, AR, dz. XXXIV, rkps 349, k. 19, Gazeta pisana, W Warszawie 14 III 1733.

26 Aneks: Relacja Löwenwolda, 2 marca 1733 r. ..., s. 66.

27 Z Warszawyd. 16 Aprilis 1733..., s. 243; „Kurier Polski” 1733, nr 169.

${ }^{28}$ Stefan Humiecki, wojewoda podolski, na początku bezkrólewia miał on stać w opozycji do kandydatury Stanisława Leszczyńskiego, jednak na sejmie elekcyjnym oddał na niego głos. Zob. A. MAcuk: Polityka rosyjska w Rzeczypospolitej w 1733 roku a kandydatura „Piasta”. „Klio. Czasopismo poświęcone dziejom Polski i powszechnym” 2014, 29, z. 2, s. 50—74. 
mazowiecki ${ }^{29}$, zarzucając mu, podobnie jak na sejmiku czerskim, bezprawne skonfederowanie województwa.

Sejmik zdominowany przez obóz narodowy jednoznacznie opowiedział się już w pierwszym punkcie instrukcji danej posłom na sejm konwokacyjny - za obroną swobód i praw Rzeczypospolitej oraz za kandydaturą Polaka na tron polski. Niechęć do kandydatury cudzoziemca była tak duża, że posłowie mieli się opowiedzieć nie tylko przeciwko cudzoziemcowi na sejmie, lecz miano go nawet nie wspominaćc ${ }^{30}$. Utrzymując przy tym, że przyszła elekcja odbędzie się szybko, bez scysji ${ }^{31}$, aby pakta konwenta do przyszłego króla były wcześniej ułożone. Wskazywano, że tylko prymas miał prawo nominować i koronować nowego króla. W stosunku zaś do dysydentów zarzucono im na sejmiku wywoływanie niezgody, czemu miał się przeciwstawić marszałek sejmiku ${ }^{32}$. Wobec tych, którzy służyli w wojsku, wysunięto analogiczne żądania jak na sejmiku czerskim. Obligowano przy tym posłów, by upomnieli się o zabezpieczenie zamku królewskiego w Krakowie, „ażeby publico non prywato Consilio" ${ }^{33}$.

Marcowy sejmik w Warszawie, pomimo że nie przebiegał spokojnie, świadczył o wzmożonej aktywności obozu narodowego w ziemi warszawskiej przed sejmem konwokacyjnym. Ważny był wysunięty na nim postulat mówiący, kto może brać udział w sejmiku: „tylko ci co wykażą genealogię w sądzie grodzkim i posesje w ziemi”" ${ }^{4}$. Można się domyśleć, że chodziło o wyeliminowanie szlachty nieosiadłej w województwie, która często była na usługach magnaterii, przyczyniając się do tumultów i rwania sejmików. W tym przypadku chodziło niewątpliwie o stronników Sasa. Wreszcie na podkreślenie zasługuje fakt, że pomimo rywalizacji politycznej i personalnej sejmik zakończył się także pomyślnie dla stronników Leszczyńskiego, gdyż w instrukcji na sejm upoważniono posłów do promowania na tron polski tylko Polaka ${ }^{35}$.

${ }^{29}$ Wojewoda mazowiecki Stanisław Poniatowski był słusznie zaliczany przez posła angielskiego G. Woodwarda i rosyjskiego F.C. von Löwenwolda do czołowych liderów obozu stanisławowskiego, zob. Rok 1733 w Polsce..., s. 132; A. MAcuk: Polityka..., s. 50.

${ }^{30}$ AGAD, ZK, rkps 62/82, k. 96, Instrukcja na sejm konwokacyjny Janowi Mniszchowi, staroście jaworskiemu i Franciszkowi Kaliszowi, miecznikowi gostyńskiemu, posłom sejmiku ziemi warszawskiej, Warszawa 11 III 1733.

${ }^{31}$ BCzart., MNK, rkps 32, k. 37, Instrukcja na sejm konwokacyjny Janowi Mniszchowi, staroście jaworskiemu, i Franciszkowi Kaliszowi, miecznikowi gostyńskiemu, posłom sejmiku ziemi warszawskiej, Warszawa 11 III 1733; H. Olszewski: Doktryny..., s. 231.

${ }^{32}$ Rzeczpospolita w dobie upadku 1700-1740. Wybór źródeł. Oprac. J.A. Gierowsкi. Wrocław 1955, s. 153.

${ }^{33}$ BCzart., MNK, rkps 32, k. 37-38, Instrukcja na sejm konwokacyjny Janowi Mniszchowi, staroście jaworskiemu, i Franciszkowi Kaliszowi, miecznikowi gostyńskiemu, posłom sejmiku ziemi warszawskiej, Warszawa [2]? III 1733; J. DygdA£A: Konfederacja..., s. 51.

${ }^{34}$ J.A. Gierowski: Sejmik..., s. 45.

${ }_{35}$ Po stronie Stanisława Leszczyńskiego opowiedział się także kasztelan warszawski Wojciech Wessel. BCzart., rkps 574, k. 52v, Rota juramentu podana do wykonania wszystkim JMP. Senato- 
Sejmik w Wiźnie obradujący w kościele parafialnym przebiegał spokojnie, do czego zresztą namawiał prymas T. Potocki. Na sejmiku zawiązano konfederację 11 marca 1733 roku, której marszałkiem obrano Adama Stanisława Rostkowskiego, starostę wiskiego, tyszowieckiego, janowskiego (na sejmie elekcyjnym oddał głos na Leszczyńskiego $)^{36}$. Łącznie do jego boku wybrano 30 konsyliarzy. Dokonano także wyboru posłów na sejm konwokacyjny, którymi zostali: S. Olszyński, podkomorzy wiski, i F. Świderski, stolnik wiski, oraz sędziów kapturowych. Na marszałka sądów kapturowych, które miały funkcjonować aż do końca elekcji, wybrano Józefa Męckowskiego, sędziego ${ }^{37}$. W instrukcji danej posłom na sejm zalecano, żeby domagali się m.in., by sejm konwokacyjny nie stał się sejmem elekcyjnym i nie został zerwany, a także ustalenia jak najszybciej terminu wolnej elekcji i potwierdzenia układów z państwami ościennymi. Wyrażono również zgodę na przystąpienie posłów do uchwalonej na sejmie konfederacji, zapowiadając przyłączenie do niej ziemi wiskiej. Nie godzono się tym samym na żadne podatki, „gdyż wolemy [wolimy] własnymi piersiami zastawiać się za wolność i jej dostojność, aniżeli z ostatnich fortun upadać"38. Postulowano, aby wojsko było opłacane z dóbr królewskich i rozprawiło się z oddziałami swawolnymi, które odłączyły się od wojska ${ }^{39}$. Pod aktem konfederacji złożyły podpis 204 osoby. Szlachta nie opowiedziała się jednak jednoznacznie za wyborem „Polaka” na tron polski.

O sejmiku ziemi wyszogrodzkiej obradującym w Wyszogrodzie pod dyrekcją podstolego wyszogrodzkiego Szawłowskiego niewiele mamy informacji, brak bowiem laud i instrukcji poselskiej ${ }^{40}$. Niewątpliwie sejmik doszedł do skutku, gdyż wyłoniono na nim posłów na sejm konwokacyjny. Zostali nimi: Maciej Szymanowski, starosta wyszogrodzki, związany z obozem saskim ${ }^{41}$, oraz Franciszek Nakwaski, pisarz ziemski wyszogrodzki ${ }^{42}$, który miał być także pozyskany przez komisarzy

rom w Gdańsku będącym przy partii króla JMP Stanisława in faworem króla Fryderyka, Gdańsk [b.d.] 1734 .

${ }^{36}$ J.A. Gierowski: Sejmik..., Załącznik nr 4.

37 BPAU i PAN, TP, rkps 8351, k. 128, Laudum konfederacji ziemi wiskiej, Wizna 11 III 1733.

${ }_{38}$ Ibidem, k. 132, Instrukcja posłom ziemi wiskiej na sejm konwokacyjny, Wizna 11 III 1733.

${ }^{39}$ Ibidem, k. 133v, Instrukcja posłom ziemi wiskiej na sejm konwokacyjny, Wizna 11 III 1733.

40 „Kurier Polski” 1733, nr 171.

${ }^{41}$ Jeszcze przed sejmem konwokacyjnym miał otrzymać od komisarzy saskich 100 dukatów. Złożył on także relację komisarzom saskim z sytuacji na Mazowszu, wskazując na ewentualnych stronników dworu saskiego na Mazowszu, do których zaliczał następujących urzędników ziemi ciechanowskiej: chorążego Szydłowskiego [?], łowczego Franciszka Duczymińskiego, stolnika Kazimierza Szymakowskiego, podczaszego [Duczymińskiego?], sędziego Michała Korniewskiego, pisarza ziemskiego i grodzkiego Kazimierza Brzozowskiego i podkomorzego nurskiego J. Narzyńskiego. Zob. J. DygdaŁa: Saskie..., s. 52-58, 62-63.

${ }_{42} \mathrm{Na}$ sejmie konwokacyjnym wystąpił zdecydowanie przeciwko dysydentom. Volumina Legum (dalej: VL). T. 3. Wyd. J. Ohryzko. Petersburg 1860, s. 299. 
saskich do partii saskiej ${ }^{43}$. Brak ich podpisów w spisie elektorów Stanisława Leszczyńskiego na sejmie elekcyjnym mógł poniekąd potwierdzać ich przynależność do obozu saskiego. Chociaż w salwach złożonych pod aktem konfederacji uchwalonej na sejmie konwokacyjnym nie zastrzegli sobie zachowania wolnej elekcji, co zazwyczaj czynili przedstawiciele obozu saskiego. Wybór wymienionych posłów wskazywał, że znaczny sukces na sejmiku mieli odnieść zwolennicy Sasa, którym udało się obsadzić poselstwa na sejm. Wnioskować stąd można, że sejmik wyszogrodzki miał niejednoznacznie opowiedzieć się za kandydaturą Polaka, w przeciwieństwie do sejmiku ziemi czerskiej czy warszawskiej. Kwestia ta niewątpliwie wymaga dalszego uściślenia. Analogicznie jak na innych sejmikach przedsejmowych, wyłoniono także poselstwo do prymasa T. Potockiego w składzie: Adam Małowiejski, łowczy wyszogrodzki ${ }^{44}$, i nijaki Pilchowski, skarbnik wyszogrodzki ${ }^{45}$.

Również sejmik ziemi zakroczymskiej w Zakroczymiu nie przebiegł bez zakłóceń. Obradował on w kościele farnym w Zakroczymiu pod laską marszałkowską Dymitra Lasockiego, miecznika zakroczymskiego (elektor Leszczyńskiego) ${ }^{46}$. Po odczytaniu listów prymasa T. Potockiego oraz biskupa płockiego A.S. Załuskiego i S. Poniatowskiego, wojewody mazowieckiego, przystąpiono do wyboru posłów ${ }^{47}$. Elekcja ta nie odbywała się spokojnie na skutek rywalizacji o funkcje poselskie na sejm konwokacyjny i do sądów kapturowych. Do sporów doszło przy głosowaniu na posłów, „a że JMP marszałek favore sui więcej należało notować krysków, więc o to niektórzy protestowali się, pretendując nowego kreskowania i stąd powstał motus, w którym rozeszli się" ${ }^{38}$. Dopiero kolejnego dnia wybrano posłów: Antoniego Radzickiego, sędziego ziemskiego zakroczymskiego, i Zbigniewa Żabickiego, chorążego ${ }^{49}$. Wyłoniono także 39 sędziów do sądów kapturowych. Ponadto wydelegowano na sejmiku dwa poselstwa, jedno do prymasa Józefa Romackiego, podstolego zakroczymskiego, i Jakuba Jaroszewskiego, miecznika płockiego, drugie zaś

${ }^{43} 30$ maja 1733 roku otrzymał on od komisarzy saskich 300 dukatów. Zob. J. DygDA£A: Saskie..., s. 64.

${ }^{44}$ Jak można sądzić, mógł być on także stronnikiem Sasa, gdyż 18 grudnia 1734 roku wziął udział w zawiązanej u boku Augusta III partykularnej konfederacji ziemi wyszogrodzkiej. BPAU i PAN, rkps 1089, k. 344, Oblata sejmiku konfederacyjnego wyszogrodzkiego, Wyszogród 18 XII 1734.

${ }^{45}$ BCzart., MNK, rkps 32, k. 84, Respons na instrukcję P.P. Małowiejskiemu, łowczemu, i Pilchowskiemu [?], skarbnikowi wyszogrodzkiemu, posłom od ziemi wyszogrodzkiej do księcia prymasa T. Potockiego, 10 IV 1733; „Kurier Polski” 1733, nr 171.

${ }^{46}$ W. Filipczak: Sejmiki ziemi zakroczymskiej 1778-1786. „Przegląd Nauk Humanistycznych” 2015, R. 14, nr 2, s. 85.

${ }^{47}$ BPAU i PAN, rkps 8354, k. 158, Laudum conventus particularis zacrocimensis, Zakroczym 11 III 1733.

${ }^{48}$ Z Warszawy d. 19 Martii 1733. W: Od Augusta Mocnego..., s. 224.

${ }^{49}$ Sędzia ziemski zakroczymski Antoni Radzicki mógł już w tym okresie sympatyzować z obozem saskim. Jego podpis widnieje pod manifestem województwa nowogrodzkiego, w którym sprzeciwiano się wyborowi Leszczyńskiego. BCzart., rkps 578, k. 297, Konfederacja praska, 5 X 1733. 
do wojewody mazowieckiego Antoniego Żabickiego, cześnika zakroczymskiego ${ }^{50}$, i Franciszka Zaborowskiego, skarbnika zakroczymskiego ${ }^{51}$.

Przeciwnicy tego wyboru zgromadzeni w Zakroczymiu obrali własnego marszałka, którym został skarbnik zakroczymski Franciszek Zaborowski. Następnie przystąpili do wyboru własnych posłów na sejm konwokacyjny i do sądów kapturowych. Ostatecznie posłami na sejm zostali podkomorzy zawskrzyński Felicjan Kuczborski (elektor Leszczyńskiego) i Józef Wągrodzki, podczaszy ziemi zakroczymskiej. Liczba wybranych posłów do sądów kapturowych miała tu wynosić 19 osób. Można przypuszczać, że jeszcze przed sejmem doszło jednak do kompromisu między zwaśnionymi fakcjami w sprawie posłów na sejm konwokacyjny, gdyż Antoni Radzicki, sędzia ziemski reprezentujący pierwszą partię, zastąpił Felicjana Kuczborskiego ${ }^{52}$. W zapisach w laudum, pod wpływem ożywienia narodowego i obaw przed utratą wolności, wskazywano posłom, aby promowali na przyszłym sejmie wybór za „pana nacjonalistę" Polaka ${ }^{53}$. Powtórzono postulaty potępiające m.in. korupcję, współpracę z innymi państwami w okresie bezkrólewia oraz skonfederowanie szlachty krakowskiej ${ }^{54}$. Obligowano posłów, aby wspólnie z innymi posłami mazowieckimi protestowali przeciwko temu na generale warszawskim. Trzeba tu dodać, że pomimo podziału sejmiku obie partie poparły kandydaturę Polaka na tron polski ${ }^{55}$.

Sejmik przedkonwokacyjny ziemi ciechanowskiej rozpoczął obrady zgodnie ze zwyczajem w kościele farnym w Ciechanowie, obierając sobie za marszałka jednomyślnie - „zgodnymi głosami” — kasztelanica ciechanowskiego Adama Radzimińskiego. Wyłoniono również posłów na sejm, którymi zostali Michał Nieborowski, podkomorzy ciechanowski ${ }^{56}$, i Kazimierz Brzozowski, pisarz ziemski i grodzki ciechanowski ${ }^{57}$. Szlachta, podobnie jak na innych sejmikach, opowiedziała się za

${ }^{50}$ Antoni Żabicki i Józef Wągrodzki na sejmie elekcyjnym oddali głosy na Stanisława Leszczyńskiego, pomimo że wcześniej podpisali się pod manifestem województwa nowogródzkiego sprzeciwiającego się jego elekcji. BCzart., rkps 574, k. 44, Manifest województwa nowogródzkiego, [b.m. i b.d.] 1733.

${ }^{51}$ BPAU i PAN, TP, rkps 8354, k. 158, Laudum conventus particularis zacrocimensis, Zakroczym 11 III 1733.

52 VL, s. 299.

53 BPAU i PAN, TP, rkps 8354, k. 164, Laudum conventus particularis zacrocimensis, Zakroczym 13 IV 1733.

${ }^{54}$ Ibidem, k. 162, Laudum conventus particularis zacrocimensis, Zakroczym 1 III 1733.

${ }_{55}$ Ibidem, k. 164, Laudum conventus particularis zacrocimensis, Zakroczym 13 IV 1733.

${ }^{56}$ Utrzymywał kontakty z komisarzami saskimi, od których miał otrzymać 600 dukatów i 20 antałów wina na przyciągnięcie szlachty do obozu saskiego. Nie dziwi więc fakt, że jako stronnik Sasa na elekcji oddał swój głos na elektora saskiego Fryderyka Augusta II. Zob. J. DygdaŁA: Saskie..., s. 63.

57 BPAU i PAN, TP, rkps 8318, k. 234, Laudum sejmiku przedkonwokacyjnego, Ciechanów 11 III 1733. Warto zauważyć, że w „Kurierze Polskim” oraz w rejestrze posłów na sejm konwokacyjny 
powszechną zgodą i porozumieniem całej Rzeczypospolitej. Prócz tego wyznaczyła także posłów do prymasa T. Potockiego, którymi zostali podstarości i sędzia grodzki ciechanowski Michał Józef Nosarzewski ${ }^{58}$ oraz starosta Antoni Nieborski, jak również sędziów kapturowych. Niestety laudum sejmikowe nie wymienia wszystkich posłów, zapis został niedokończony. W zachowanej instrukcji znalazły się punkty mówiące o konieczności utrzymania wolności, swobód i wiary katolickiej.W kwestii wyboru króla, zalecano tylko takiego kandydata, który wcześniej na sejmie konwokacyjnym był „naznaczonym przez stany Rzeczpospolitej” ${ }^{59}$. Z zachowanego fragmentu instrukcji można przypuszczać, że szlachta, podobnie jak na sejmiku wyszogrodzkim, niejednoznacznie opowiedziała się za Polakiem ${ }^{60}$.

$\mathrm{Z}$ drugiej niepełnej instrukcji wynika, że posłowie mieli domagać się od regimentarza koronnego ubezpieczenia granicy z Prusami (gdzie dochodziło do częstych porwań ludzi) oraz wynagrodzenia krzywd wyrządzonych przez Brandenburczyków duchowieństwu katolickiemu. Wnioskowano, aby wakujące buławy hetmańskie przez nowo obranego króla były rozdane. Żądano usunięcia oficerów cudzoziemskich z regimentów, którzy mieli być zastąpieni szlachtą polską, a komendy miały być w języku polskim ${ }^{61}$. Także na urzędach skarbowych miała zasiadać tylko szlachta polska. Instrukcja podniosła również kwestię aukcji wojska. Zwrócono przy tym uwagę na konieczność utrzymania równowagi w ciężarach ponoszonych przez ziemie na wyprawy komputowe. Dotyczyło to zwłaszcza województw południowo-wschodnich, np. województwa ruskiego, które niewiele płaciło na wojsko w porównaniu $\mathrm{z}$ województwem mazowieckim. Pogłówne żydowskie miało być przeznaczone na aukcje wojska. Na sejmiku wybrano również posłów do J.W. Mniszcha, marszałka wielkiego koronnego, którymi zostali: Michał Szymakowski, stolnikiewicz ciechanowski (elektor Leszczyńskiego), i Michał Korniewski, sędzia ziemi ciechanowskiej ${ }^{62}$. Warto wspomnieć, że w zachowanych lauduach brak jest wyraźnego poparcia na sejmiku kandydatury Polaka.

podano jednak inne nazwisko drugiego posła, miał nim zostać Szydłowski, chorąży ciechanowski. „Kurier Polski” 1733, nr 169; BCzart., MNK, rkps 32, k. 155, Rejestr posłów na sejm konwokacyjny in Anno 1733, 27 Aprilis odprawować się mający z województw ziem i powiatów obranych, 1733.

58 Stronnik Stanisława Leszczyńskiego, wziął udział w generalnej konfederacji dzikowskiej zawiązanej w obronie Stanisława Leszczyńskiego.

${ }_{59}$ BPAU i PAN, TP, rkps 1856, k. 240, Instrukcja dana posłom na sejm konwokacyjny, Ciechanów 11 III 1733, b.d.

${ }^{60}$ J. Dygda£a: Saskie..., s. 58.

${ }^{61}$ AGAD, ZIP, t. 3, k. 217, „Relacye albo Przyczyny kochającego Ojczyznę Syna, które by przynależało, aby były promowane i utrzymywane od IMci Panów Posłów na sejmie convocationis, To jest żeby w Piechocie Polskiej Zaciągu Cudzoziemskiego w Ćwiczeniu Żołnierza zażywano Języka Polskiego, a nie innego 1733 z Warszawy"; BPAU i PAN, TP, rkps 1856, k. 242, (Kopia drugiej instrukcji) Instrukcja dana posłom na sejm konwokacyjny, Ciechanów 11 III 1733.

${ }_{62}$ Ibidem, k. 249, Instrukcja posłom Michałowi Szymakowskiemu, stolnikiewiczowi ciechanowskiemu, i Michałowi Korniewskiemu, sędziemu ziemi ciechanowskiej, do J.W. Mniszcha, marszałka wielkiego koronnego, Ciechanów 11 III 1733. 
Burzliwy przebieg miał sejmik ziemi łomżyńskiej obradujący w Łomży ${ }^{63}$, gdzie - jak twierdził Bronisław Wojciechowski - stosunkowo duże wpływy miało stronnictwo saskie, któremu liderował łowczy łomżyński Michał Maurycy Suski ${ }^{64}$. Podobnie jak na sejmiku ziemi warszawskiej, doszło tu do rywalizacji o funkcję marszałka sejmiku między starostą łomżyńskim Ignacym Przyjemskim, który zagajał obrady sejmiku ${ }^{65}$, a chorążym łomżyńskim Janem Staniszewskim. W celu uspokojenia obrad zawiązano na sejmiku partykularną konfederację, na której czele stanął I. Przyjemski. Skupiła się wokół niego większość urzędników ziemskich ${ }^{66}$. Skądinąd był on osobą sympatyzującą ze Stanisławem Leszczyńskim, chociaż nie ujawniał swoich poglądów w okresie bezkrólewia ${ }^{67}$. W tej sytuacji chorąży łomżyński J. Staniszewski popierany przez nieliczną szlachtę przystąpił do konfederacji, obejmując funkcję konsyliarza. Drugim konsyliarzem został Mikołaj Suski, sędzia ziemski zambrowski i rotmistrz (elektor Leszczyńskiego) ${ }^{68}$. Następnie wraz z marszałkiem złożyli oni przysięgę, że „przy wierze ś. (świętej) katolickiej rzymskiej, przy prawach, swobodach i wolnościach w zgodzie, jedności i miłości zostawać będą, cudzoziemca na tron promować nie będą" ${ }^{69}$. Po przeczytaniu listów prymasa, biskupa płockiego i wojewody mazowieckiego dokonano wyboru posłów na sejm konwokacyjny, którymi zostali: podkomorzyc łomżyński Tomasz Zieliński (stronnik Stanisława Leszczyńskiego) i łowczy łomżyński M.M. Suski ${ }^{70}$. Ponadto wybrano sędziów do sądów

${ }^{63}$ Ziemia łomżyńska była największą z ziem województwa mazowieckiego, liczyła 4260 km², zob. J.A. Gierowski: Sejmik..., s. 25.

${ }^{64}$ Miał on otrzymać od posłów saskich pieniądze na promowanie Wettina. AGAD, ZIP, t. 3 , k. 215, Kopia listu A.S. Załuskiego, biskupa płockiego do ziemi łomżyńskiej, Warszawa 6 III 1733; ibidem, k. 215, Respons na ten list od ziemi łomżyńskiej, marszałka konfederacyjnego, Łomża 11 III 1733; B. Wojciechowsкi: Ignacy Przyjemski, starosta łomżyński. Polityk lokalny czasów saskich. Olsztyn 2004, s. 29.

${ }^{65}$ Zarówno w stosunku do Michała Maurycego Suskiego, jak i Ignacego Przyjemskiego wojewoda mazowiecki Stanisław Poniatowski jeszcze przed rozpoczynającym się sejmikiem w Łomży podjął działania - zresztą bezskuteczne - mające na celu pozyskanie ich do współpracy z obozem stanisławowskim. AGAD, ZIP, t. 8, k. 98, List S. Poniatowskiego do I. Przyjemskiego, Warszawa 1 III 1733; ibidem, k. 99, List S. Poniatowskiego do M. Suskiego, Solec 1 III 1733; ibidem, k. 98, List I. Przyjemskiego do S. Poniatowskiego, Kupiska 12 III 1733; B. WојсіесношsкI: Ignacy Przyjemski..., s. 30, 31 .

${ }^{66}$ AGAD, ZIP, t. 3, k. 296, Relacja sejmiku electionis posłów na sejm convocationis, Łomża 11 III 1733.

${ }^{67}$ AGAD, ZIP, t. 8, k. 107, List M.M. Suskiego do I. Przyjemskiego, Warszawa 9 IV 1733; ibidem, k. 103, List M.M. Suskiego do I. Przyjemskiego, Warszawa 26 III 1733.

${ }^{68}$ Wprawdzie nie udało się ustalić, jak głosował na polu elekcyjnym, jednak z całą pewnością brał on czynny udział w zawiązaniu partykularnej konfederacji ziemi łomżyńskiej 19 lipca 1734 roku opowiadającej się po stronie Stanisława Leszczyńskiego. BPAU i PAN, TP, rkps 8332, k. 268, Laudum konfederacji ziemi łomżyńskiej, Łomża 11 VIII 1733.

${ }^{69}$ Ibidem, rkps 8332, k. 256, Laudum ziemi łomżyńskiej, Łomża 11 III 1733.

70 BPAU i PAN, rkps 1856, k. 1061, Instrukcja posłom Tomaszowi Zielińskiemu, podkomorzycowi łomżyńskiemu, i Maurycemu Suskiemu, łowczemu łomżyńskiemu, Łomża 11 III 1733. W okre- 
kapturowych, łącznie 52 osoby, oraz pułkownika mającego prowadzić szlachtę ziemi łomżyńskiej na przyszłą elekcję, którym został stronnik obozu stanisławowskiego chorąży łomżyński J. Staniszewski. Rotmistrzami zaś wybrano: w powiecie łomżyńskim wspomnianego płk. J. Staszewskiego, w powiecie zambrowskim - Antoniego Rostkowskiego, podczaszego łomżyńskiego (stronnika Stanisława Leszczyńskiego), w kolińskim - Wacława Kisielnickiego, podstolego łomżyńskiego. Należy zauważyć, że obsadzenie tych funkcji przez stronników Stanisława Leszczyńskiego świadczyło o ich przewadze nad obozem saskim. Jednocześnie wybrano posłów do prymasa: Hilarego Trzoskę, stolnika nowogrodzkiego, i Józefa Mrozowskiego, komornika ziemskiego ostrołęckiego ${ }^{71}$. Warto zaznaczyć, że w instrukcji krytykowano także wydarzenia, do których doszło w województwie krakowskim ${ }^{72}$.

Instrukcja na sejm nakazywała posłom domagać się zachowania wolnej i zgodnej elekcji, tak aby na polu elekcyjnym nie doszło do scysji, a także lepszego podobnie jak na sejmiku ciechanowskim - zabezpieczenia granicy z Prusami ${ }^{73}$. W kwestii kandydata do tronu polskiego nakazywano promować patriotę Polaka, a nie cudzoziemca ${ }^{74}$. Nie wykluczono jednak cudzoziemców, ostateczną decyzję w tej sprawie odkładano do sejmu elekcyjnego. Niewątpliwie był to sukces stronników Sasa, którzy w ekskluzji cudzoziemca dopatrywali się zamachu na wolną elekcję $^{75}$. Decyzja ta spotkała się z krytyką I. Przyjemskiego przez stronników Leszczyńskiego. Sam I. Przyjemski winą za odłożenie przysięgi obarczał dotychczasowego przeciwnika - J. Staniszewskiego, ten z kolei I. Przyjemskiego i M. Suskiego ${ }^{76}$. Posłowie zobowiązani byli $\mathrm{w}$ instrukcji do sprzeciwienia się przyjazdowi na pole elekcyjne senatorów i ministrów w obstawie prywatnych wojsk ${ }^{77}$. W dokumen-

sie sejmu konwokacyjnego łowczy łomżyński miał być już pozyskany przez starostę mielnickiego Karola Sedlnieckiego do partii saskiej. W maju miał otrzymać od komisarzy saskich beczkę wina i tabakierkę. Na sejmie elekcyjnym oddał jednak swój głos jeszcze na Stanisława Leszczyńskiego. Wkrótce jednak przeszedł na Pragę do obozu saskiego. BCzart., rkps 578, s. 63, k. 297, Konfederacja praska, 5 X 1733; J. DygdaŁa: Saskie..., s. 53.

71 AGAD, ZIP, t. 8, k. 103, List M.M. Suskiego do I. Przyjemskiego, Warszawa 26 III 1733.

72 BPAU i PAN, TP, rkps 8332, k. 255, Instrukcja posłom Hilaremu Trzoskowskiemu, stolnikowi nowogrodzkiemu, i Józefowi Mrozowskiemu, komornikowi ziemskiemu ostrołęckiemu, do prymasa Potockiego, Łomża 11 III 1733.

${ }^{73}$ Już w lutym 1733 roku regimentarz koronny Stanisław Poniatowski podjął pewne działania mające na celu zabezpieczenie granicy z Prusami, przesuwając chorągwie polskie w okolicę Nowogrodu, Kolna i Szczuczyna, które miały być pod komendą starosty wiskiego Adama Rostkowskiego. AGAD, ZIP, t. 8, k. 97, List S. Poniatowskiego do E. Szembekówny, Warszawa 20 II 1733; ibidem, k. 99, List I. Przyjemskiego do A.S. Rostkowskiego, [b.m.] 29 III 1733; ibidem, k. 114, List A. Rostkowskiego do I. Przyjmskiego, 16 VI 1733; B. Wojciechowsкi: Ignacy Przyjemski..., s. 30.

${ }^{74}$ „Kurier Polski” 1733, nr 169, „Suplement do Gazet Polskich”.

75 B. Wojciechowski: Ignacy Przyjemski..., s. 31.

${ }^{76}$ Ibidem.

77 AGAD, ZIP, t. 3, k. 287-293, Instrukcja Ichm Panom Tomaszowi Zielińskiemu, podkomorzycowi i Michałowi Suskiemu, łowczemu, łomżyńskim posłom ziemi łomżyńskiej na sejm konwo- 
cie potępiono wszelkie szkodliwe fakcje i prywatną korespondencję z państwami ościennymi, wrogo nastawionymi do kandydatury Leszczyńskiego. Nie zabrakło także postulatów skierowanych przeciw dysydentom ${ }^{78}$.

Dla zwiększenia bezpieczeństwa Rzeczypospolitej posłowie mieli zabiegać o poprawę stosunków z państwami ościennymi oraz o aukcję wojska. Podobnie jak na sejmiku ciechanowskim, mieli postulować równomierne obciążenia podatkami województw. W atmosferze narastającej niechęci do dysydentów domagano się ich usunięcia $\mathrm{z}$ wojska. W regimentach nie miało być żadnego dysydenta, „choćby był i Polak". Poza tym miała być uregulowana płaca w wojsku koronnym. Generalnie rzecz biorąc, przebieg wydarzeń na sejmiku należy ocenić pozytywnie dla obozu narodowego, pomimo znacznych wpływów na nim stronników Sasa.

Sejmik różański przedkonwokacyjny zebrał się w kościele parafialnym w Różanie za uniwersałem prymasa T. Potockiego. Marszałkiem koła rycerskiego został Wojciech Karski, stolnik ziemi różańskiej i makowskiej. Do pomocy zaś wybrano dwóch asesorów: Michała Zorawskiego, podczaszego rożańskiego ${ }^{79}$, i Stefana Dąbrowskiego, podsądka ziemi rożańskiej ${ }^{80}$. Zarówno marszałek sejmiku, jak i asesorowie na elekcji opowiedzieli się po stronie Stanisława Leszczyńskiego. Posłami na sejm obrano: Błażeja Krasińskiego, prosnyskiego, nowomiejskiego starostę, i Jana Rzechowskiego, pisarza grodzkiego rożańskiego (obydwaj to elektorowie Leszczyńskiego $)^{81}$. Zostali oni także wydelegowani na obrady generału mazowieckiego, które miały się rozpocząć jeszcze przed sejmem konwokacyjnym ${ }^{82}$. Na sejmiku wybrano również 18 posłów do sądów kapturowych. Podobnie jak na innych sejmikach, zgromadzona szlachta, zgodnie $\mathrm{z}$ wytycznymi prymasa, opowiedziała się za utrzymaniem całości Rzeczypospolitej. W laudum nie wypowiedziano się jednak na temat kandydatury do tronu polskiego. Zalecając tym samym posłom, aby zabiegali na sejmie o zabezpieczenie granic, aukcję wojska oraz obmyślenie na nie podatków. Pojawił się także postulat relegowania z wojska nadmiernej liczby oficerów. Pieniądze dla nich przeznaczone miały być wykorzystane na zaciąg nowych żołnierzy ${ }^{83}$.

Sejmik liwski obradował w stołecznym mieście tej ziemi w Liwie. Jak donosił „Kurier Polski”, doszło na nim do tumultu podczas wyboru marszałka, w wyniku

kacyjny warszawski od sejmiku sub vinikulo confederationis obranym w Łomży Dnia 11 miesiąca marca Roku Pańskiego 1733 dana.

${ }^{78}$ Ibidem, k. 251.

79 Stronnik Stanisława Leszczyńskiego, w 1734 roku został marszałkiem partykularnej konfederacji zawiązanej w jego obronie.

${ }^{80}$ Stefan Dąbrowski, podsądek ziemi rożańskiej, stronnik Stanisława Leszczyńskiego, wziął udział 1734 roku w zawiązanej przy jego boku partykularnej konfederacji.

${ }^{81}$ W „Kurierze Polskim” błędnie zapisano nazwiska posłów — zamiast Rzechowski i Krasiński jest Orzechowski i Rasiński. Zob. „Kurier Polski” 1733, nr 180; VL, s. 299.

${ }^{82}$ BPAU i PAN, TP, rkps 8337, k. 440, 441, Laudum sejmiku rożyckiego, Różan 11 III 1733.

${ }^{83}$ Ibidem. 
czego zabito niejakiego Dąbrowskiego, burgrabiego liwskiego, po czym sejmik został zalimitowany ${ }^{84}$. Dopiero 18 marca 1733 roku ponownie wszczął obrady pod marszałkostwem regenta grodzkiego ziemi liwskiej Karola Dąbrowskiego ${ }^{85}$. Posłami na sejm wybrano Józefa Oborskiego, podkomorzego liwskiego, i Fabiana Zukowskiego, skarbnika ziemi liwskiej. Instrukcja sejmiku liwskiego nakazywała posłom, aby domagali się zaprzestania ingerencji cudzoziemców w sprawy rządów Rzeczypospolitej, a na czas sejmu konwokacyjnego i elekcyjnego opuścili Warszawę. Pozostałe wytyczne dotyczyły zabezpieczenia granic polskich, uregulowania podatku na wojsko tak, aby był on jednakowy dla wszystkich województw, a także obciążenia podatkiem także dóbr biskupich. Chorągwie komputowe armii koronnej miały być utrzymywane w komplecie, a musztra odprawiana po polsku. Szlachta nakazywała także rugowanie dysydentów $\mathrm{z}$ wojska $-\mathrm{w}$ tym także z urzędów, na których zasiadać miała tylko szlachta - „osobliwie poczmagistrów, żeby korespondencjami Rzeczypospolitej nie mieszali”" ${ }^{\text {"26 }}$. Posłowie opowiedzieć się mieli przeciwko wszelkim werbunkom wojska w okresie bezkrólewia i zbliżaniu się chorągwi nadwornych do pola elekcyjnego. Dotychczasowe układy z państwami ościennymi miały być utrzymane, „innych zaś nowych nie stanowic" ${ }^{87}$. W sprawie kandydatów do korony sejmik zajął jednoznaczne stanowisko, opowiadając się za kandydaturą Polaka. Posłowie liwscy, podobnie jak czerscy, mieli się także opowiedzieć za zachowaniem integralności Rzeczypospolitej. Nic więc dziwnego, że szlachta podkreślała w instrukcji konieczność utrzymania Kurlandii, Drahimia i Elbląga ${ }^{88}$.

Warto zauważyć, że wyraźny wpływ na instrukcję poselską ziemi liwskiej wywarli stronnicy kasztelana czerskiego K.F. Rudzińskiego i Czartoryskich, którzy mieli tu znaczne wpływy ${ }^{89}$. Potwierdzają to także lauda sejmiku liwskiego i czerskiego, w których można zauważyć zbieżność niektórych haseł z postulatami zawartymi w instrukcjach poselskich. Niewątpliwie sprzyjał temu fakt znacznej liczby stronników Stanisława Leszczyńskiego w ziemi liwskiej, tudzież sąsiedztwo wymienionych ziem.

84 „Kurier Polski” 1733, nr 169.

${ }^{85}$ BPAU i PAN, TP, rkps 8322, k. 437, Instrukcja posłom ziemi liwskiej na sejm konwokacyjny, Liw 11 III 1733.

${ }^{86}$ Żydzi nie mieli być dopuszczani do komór celnych, żup solnych, dóbr stołecznych, które były zarezerwowane tylko dla szlachty polskiej. BPAU i PAN, TP, rkps 8322, k. 436, Instrukcja posłom ziemi liwskiej na sejm konwokacyjny, Liw 18 III 1733; T. CIESIELSKI: Sejmiki wobec kwestii bezpieczeństwa publicznego w czasach Augusta III - milicje wojewódzkie. W: Po unii - sejmiki szlacheckie w Rzeczypospolitej XVI-XVIII wieku. Red. H. Lulewicz. Siedlce 2013, s. 320.

87 BPAU i PAN, TP, rkps 8322, k. 435.

${ }^{88} \mathrm{~W}$ kwietniu posłowie liwscy mieli audiencję u prymasa T. Potockiego, w trakcie której postulowali usunięcie posłów cudzoziemskich z Warszawy, Z Warszawy d. 23 Aprilis 1733..., s. 247.

89 J. DygdaŁa: Saskie..., s. 58. 
Ostatnim sejmikiem przedsejmowym, który rozpoczął obrady, był sejmik w Nurze $^{90}$, na którym posłami na sejm konwokacyjny wybrano Jakuba Narzymskiego, podkomorzego nurskiego, zaliczanego przez komisarzy saskich do stronników Sasa $^{91}$ (na sejmie elekcyjnym podpisał się pod kandydaturą Sasa) ${ }^{92}$, i Krzysztofa Godlewskiego, starostę ziemi nurskiej. Pomimo że był on zaliczany także przez komisarzy saskich do stronników Sasa ${ }^{93}$, oddał jednak głos na sejmie elekcyjnym na Stanisława Leszczyńskiego. Jak można sądzić, taka postawa mogła wynikać z jego nieszczerych wcześniejszych intencji wobec Sasa lub z obaw przed stronnikami Leszczyńskiego o majątek.

Zarazem na sejmiku wybrano także posłów do prymasa T. Potockiego: Renarda, cześnika nurskiego, i Boguckiego, burgrabię krakowskiego. Brak laudum i instrukcji w przypadku tego sejmiku nie pozwala na zaprezentowanie głoszonych na nim haseł. Jakkolwiek postulowanie wykluczenia dysydentów przez posła K. Godlewskiego, starostę nurskiego, na sejmie konwokacyjnym mogło świadczyć, że hasło to było także zawarte w instrukcji sejmiku nurskiego ${ }^{94}$. Nie ulega jednak wątpliwości, że wybór wzmiankowanych posłów należy uznać za chwilowy sukces obozu saskiego na sejmiku, na którym udało się pozyskać część zgromadzonej szlachty. Trudno jednak stwierdzić, jak liczna była to grupa.

Hasła głoszone w laudach i instrukcjach poselskich zostały potwierdzone przez szlachtę na sejmiku generału mazowieckiego, który rozpoczął obrady już 18 marca 1733 roku. Obrady zagajał Kasper Suffczyński, podstoli, poseł czerski. Przybyli na nie jednakże nieliczni posłowie, co uniemożliwiało opracowanie instrukcji poselskiej. W tej sytuacji obrady zostały zalimitowane ${ }^{95}$. Wznowiono je 25 kwietnia pod laską marszałkowską Antoniego Sebastiana Dębowskiego ${ }^{96}$, referendarza koron-

90 W. Filipczak: Sejmiki ziemi nurskiej 1780-1786. „Przegląd Nauk Historycznych” 2014, R. 13, nr 1, s. 23.

${ }^{91}$ Miał on początkowo otrzymać od posłów saskich „300 dukatów i 10 antałów wina”. Wkrótce Narzymski wraz z Michałem Nieborskim otrzymali dodatkowo 500 dukatów na pozyskanie nowych stronników Sasa wśród szlachty. Zob. J. DygdaŁa: Saskie..., s. 63.

92 Wziął on udział także w konfederacji praskiej popierającej Augusta III. BCzart., rkps 1689, k. 293, Konfederacja Praska, 5 X 1733.

${ }_{93} \mathrm{~W}$ „Kurierze Polskim” podano, jakoby drugim posłem na sejm został wybrany z ziemi nurskiej Stanisław Brzeziński, chorąży nurski, późniejszy marszałek partykularnej konfederacji ziemi łomżyńskiej zawiązanej w lipcu 1734 roku u boku Stanisława Leszczyńskiego. Nie potwierdzają tego rejestr posłów na sejm konwokacyjny ani Volumina Legum. Zob. „Kurier Polski” 1733, nr 169; BCzart., MNK, rkps 32, k. 155, Rejestr posłów na sejm konwokacyjny in Anno 1733, 27 Aprilis odprawować się mający z województw ziem i powiatów obranych.

${ }_{94}$ BCzart., rkps 571, k. 175, Diariusz sejmu konwokacyjnego, 27 IV 1733.

${ }_{95}$ Cichocki podawał w swej gazecie pisanej inne powody zalimitowania obrad, które miały wynikać z próby pogodzenia zwaśnionych stron lub wybrania nowych posłów. Z Warszawyd. 19 Martii 1733..., s. 223. Zob. Aneks: Relacja Löwenwolda, 8 marca 1733 r. W: V.I. GeRJE: Barba..., s. 71.

${ }_{96}$ Już w okresie trwania sejmu konwokacyjnego Ewa Szklarska zaliczała go do stronników Sasa, zob. E. SzKLA RSKa: Kwestia..., s. 573. 
nego płockiego. Obrady zdominował obóz prostanisławowski ${ }^{97}$, w związku z czym generał mazowiecki opowiedział się za kandydaturą Polaka. Tym samym sprzeciwił się wszelkim zamieszkom w kraju, prywatnym zjazdom i fakcjom, dążącym do osadzenia własnego kandydata na tronie przy wsparciu państw ościennych ${ }^{98}$. Tak więc dla lepszego zabezpieczania spokoju postulował, aby komenda nad wojskiem w Krakowie pozostała przy regimentarzu generalnym S. Poniatowskim ${ }^{99}$. Opowiedziano się także za aukcją wojska z „obmyśleniem realnej płacy”. Nie zabrakło również głosów antydysydenckich domagających się rugowania posłów dysydenckich z obrad sejmu konwokacyjnego oraz zachowania integralności Rzeczypospolitej ${ }^{100}$. Jak zauważył w swojej pracy Józef Gierowski, na generale nie zawiązano konfederacji wojewódzkiej, „zapowiadając jedynie, że na konwokacji posłowie mazowieccy będą się domagać aprobaty konfederacji ziemskich" ${ }^{101}$.

W obradach sejmu konwokacyjnego w Warszawie (27 kwietnia-23 maja 1733) wzięło udział 20 posłów z województwa mazowieckiego ${ }^{102}$. Wszyscy posłowie złożyli przysięgę na wykluczenie cudzoziemca. Uczynili to nawet znaczący stronnicy Sasa pod naciskiem opinii publicznej. Tylko trzech posłów zastrzegło sobie w salwach konieczność zachowania wolnej elekcji i wolnego głosu.

Konstatacja płynąca z opisanych zdarzeń upoważnia do stwierdzenia, że obóz narodowy w województwie mazowieckim zarówno na sejmikach przedsejmowych, jak i na sejmie konwokacyjnym uzyskał zdecydowaną przewagę nad stronnikami $\operatorname{Sasa}^{103}$. Nie jest łatwo jednoznacznie określić, ilu wśród zwolenników obozu narodowego było już zdeklarowanych stronników Leszczyńskiego. Nie oznaczało to jednak, że sejmiki przebiegały spokojnie, a stronnicy Sasa zrezygnowali z poparcia swojego kandydata, czego wyraz dano także na późniejszych sejmikach relacyjnych.

Uszczegóławiając, warto odnotować, że szlachta województwa mazowieckiego dość licznie przybyła na obradujące w bezkrólewiu sejmiki. Podczas obrad sejmi-

${ }_{97}$ BCzart., MNK, rkps 50, k. 493, Laudum Generału Województw i ziem X. Mazowieckiego, Warszawa 25 IV 1733; J.A. Gierowski: Sejmik..., s. 14.

${ }^{98}$ BPAU i PAN, TP, rkps 8334, k. 343, Laudum Generału Województw i ziem X. Mazowieckiego, Warszawa 25 IV 1733.

${ }^{99}$ Skądinąd postulat ten został w pełni zrealizowany przez regimentarza koronnego Stanisława Poniatowskiego, jeszcze przed sejmem elekcyjnym wojewoda krakowski Teodor Lubomirski wyprowadził swoje prywatne oddziały z Krakowa, które zostały zastąpione regimentem gwardii pieszej koronnej, pod komendą płk. Antoniego Ossolińskiego. AGAD, Archiwum Publiczne Potockich (dalej: APP), rkps 169, k. 191, List S. Poniatowskiego do T. Lubomirskiego, Warszawa 1 VIII 1733.

${ }^{100}$ BCzart., MNK, rkps 50, k. 497, Laudum Generału Województw i ziem X. Mazowieckiego, Warszawa 25 IV 1733.

101 J.A. Gierowski: Sejmik..., s. 72.

102 „Kurier Polski” 1733, nr 180.

103 AGAD, ZIP, t. 8, k. 104, List M. Suskiego do I. Przyjemskiego, Warszawa 31 III 1733. 
ków przedkonwokacyjnych w województwie nie wysunięto oficjalnie kandydatury Leszczyńskiego na króla Polski, głoszono tylko hasła wyboru Polaka, mając jednak na uwadze jego osobę. Na dziesięć sejmików przedkonwokacyjnych obradujących w województwie mazowieckim pięć zdecydowanie opowiedziało się za kandydaturą Polaka na tron polski: czerski, warszawski, zakroczymski, łomżyński i liwski. Jednoznacznego poparcia dla kandydatury Polaka zabrakło na sejmikach: wiskim, wyszogrodzkim, ciechanowskim. Niestety nie udało się ustalić postawy szlachty na sejmiku nurskim i różańskim. Chociaż w przypadku tego ostatniego można domniemywać, że większość szlachty opowiedziała się tu także za kandydaturą Polaka, gdyż na sejmiku relacyjnym wykonano przysięgę na akt konfederacji. Trudno w tej sytuacji mówić o jedności wśród szlachty województwa mazowieckiego. Trzeba jednak zauważyć, że pierwszy sondaż opinii szlacheckiej dokonany na marcowych sejmikach przedkonwokacyjnych wskazywał na przewagę w województwie mazowieckim obozu narodowego nad zwolennikami Sasa. Skądinąd potwierdził to sejmik generału mazowieckiego, który jednoznacznie opowiedział się za kandydaturą Polaka. Zasadniczy cel sejmików przedsejmowych - polityczna aprobata kandydatury Polaka przez szlachtę województwa mazowieckiego - został więc osiągnięty. Jednocześnie sejmiki czerski, warszawski, zakroczymski, ciechanowski, łomżyński ustosunkowały się negatywnie do ambitnych planów zdobycia korony przez wojewodę krakowskiego T. Lubomirskiego.

W województwie mazowieckim nie obyło się także bez zakłóceń obrad sejmikowych na skutek rywalizacji poszczególnych fakcji o funkcję marszałkowską, doszło do nich m.in. na sejmikach warszawskim, zakroczymskim, łomżyńskim, liwskim. Na uwagę zasługuje fakt, że znaczna część szlachty, która poparła Leszczyńskiego, to szlachta drobna i gołota dominująca w tym województwie, która nie pełniła żadnych urzędów.

Kryzys związany z bezkrólewiem znalazł odzwierciedlenie także $\mathrm{w}$ instrukcjach poselskich, w hasłach troski o bezpieczeństwo publiczne Rzeczypospolitej. Uświadomiono sobie konieczność lepszego zabezpieczenia granic i aukcji wojska, co uwidoczniło się w szczególności na sejmikach ziemi czerskiej, ciechanowskiej, łomżyńskiej, różańskiej. Wojsku zaczęto także przypisywać rolę policji wojewódzkiej. Aczkolwiek brak było konkretnych programów reform fiskalnych umożliwiających realizację przedstawionych postulatów, a pojawiające się hasła nie naruszały zasad ustrojowych państwa i sprowadzały się raczej do usprawnienia procedury ściągania podatków w ramach istniejącego systemu podatkowego. Jednocześnie trzeba wiedzieć, że i te hasła spotkały się z krytyką części konserwatywnej szlachty na przykład na sejmiku wiskim. Na sejmikach czerskim, warszawskim, łomżyńskim, liwskim pojawiły się także hasła pozbawienia różnowierców i cudzoziemców praw politycznych. Częściowo wynikało to $\mathrm{z}$ faktu, iż Kościół katolicki posiadał tu znaczne wpływy, a szlachta była zainteresowana zapewnieniem sobie wyłączności na urzędy publiczne przynoszące znaczne dochody. 
Rzeczą charakterystyczną jest, że w kwestii polityki zagranicznej szlachta mazowiecka opowiadała się za pokojowym rozstrzyganiem sporów, stąd postulaty rozwiązywania konfliktów przez potwierdzanie wcześniejszych układów z państwami ościennymi, głoszone m.in. na sejmikach czerskim, wiskim, łomżyńskim i liwskim. Tak więc na sejmikach przedsejmowych uwydatniły się idee integracji wewnętrznej Rzeczypospolitej jako najlepszego sposobu zabezpieczenia się przed ingerencją państw ościennych. Oczywiście, postulat zachowania dobrych stosunków z państwami ościennymi w ówczesnej sytuacji politycznej był raczej niemożliwy do zrealizowania. Wynikało to $\mathrm{z}$ ich wrogiego nastawienia do wyboru Stanisława Leszczyńskiego. Polska za cenę utrzymania dobrych stosunków z nimi musiałaby zrezygnować z jego wyboru, czego jednak większość szlachty, w tym $\mathrm{z}$ województwa mazowieckiego, nie aprobowała.

\section{Bibliografia}

Askenazy S.: Przedostatnie bezkrólewie. W: S. Askenazy: Dwa stulecia XVIII i XIX. Badania i przyczynki. T. 1. Warszawa 1901, s. 1-174.

Boyé P.: Stanisław Leszczynski et le troisième traité de Vienne. Paris 1898.

Ciesielski T.: Sejmiki wobec kwestii bezpieczeństwa publicznego w czasach Augusta III - milicje wojewódzkie. W: Po unii - sejmiki szlacheckie w Rzeczypospolitej XVI-XVIII wieku. Red. H. LULEWICZ. Siedlce 2013, s. 319-330.

DygdaŁA J.: Episkopat rzymskokatolicki doby saskiej. Aktywność w życiu publicznym. W: Między monarchą a demokracją. Studia $z$ dziejów Polski XV-XVIII wieku. Red. A. Sucheni-GrabowsKa, M. ŻARYN. Warszawa 1994, s. 332-376.

DygdaŁA J.: Konfederacja krakowska Teodora Lubomirskiego z początków bezkrólewia 1733 roku a polityka Austrii wobec Rzeczypospolitej. W: Trudne stulecia. Studia z dziejów XVII i XVIII wieku, ofiarowane Profesorowi Jerzemu Michalskiemu w siedemdziesiątą rocznicę urodzin. Red. Ł. KĄDZIELA. Warszawa 1994, s. 46-54.

DyGDAŁA J.: Saskie próby infiltracji środowisk szlacheckich podczas bezkrólewia 1733 roku. „Kwartalnik Historyczny" 2003, R. 110, z. 4, s. 47-70.

FilipczaK W.: Sejmiki ziemi nurskiej 1780-1786. „Przegląd Nauk Historycznych” 2014, R. 13, nr 1, s. $24-62$.

FILIPCZAK W.: Sejmiki ziemi zakroczymskiej 1778-1786. „Przegląd Nauk Historycznych” 2015, R. 14, nr 2, s. $86-121$.

GerJe V.J.: Borba za Pol'skij prestoł v 1733 godu. Moskva 1862.

Gierowski J.A.: Sejmik generalny Księstwa Mazowieckiego. Wrocław 1948.

Kantecki K.: Stanisław Poniatowski, kasztelan krakowski ojciec Stanisława Augusta. T. 2. Poznań 1880.

Rok 1733 w Polsce od śmierci Augusta II do elekcji Augusta III, podłóg raportów dyplomatycznych ajentów angielskich. „Przegląd Poznański” 1861, t. 32, z. 2, s. 119-134.

Macuk A.: Polityka rosyjska w Rzeczypospolitej w 1733 roku a kandydatura „Piasta”. „Klio. Czasopismo poświęcone dziejom Polski i powszechnym" 2014, 29, z. 2, s. 50-110. 
Maliszewski K.: Szlachecka opinia publiczna wobec powtórnej elekcji Stanisława Leszczyńskiego w 1733 r. Próba zarysowania problemu w świetle ówczesnej prasy rękopiśmiennej. „Rocznik Gdański" 1986, 46, z. 1, s. 69-80.

Matuszewicz M.: Diariusz życia mego. T. 1: 1714-1757. Oprac. B. Królıkowski. Warszawa 1986. Olszewski H.: Doktryny prawno-ustrojowe czasów saskich (1697-1740). Warszawa 1961.

PAwIŃski A.: Polska XVI wieku pod względem geograficzno-statystycznym. T. 5:Źródła dziejowe. T. 16. Warszawa 1895.

RudziŃsкi W.: Franciszek Rudziński. W: Polski słownik biograficzny. T. 33. Wrocław 1991.

Rzeczpospolita w dobie upadku 1700-1740. Wybór źródet. Oprac. J.A. GIERowsKi. Wrocław 1955.

SzKLARSKA E.: Kwestia wykluczenia cudzoziemca od tronu na sejmie konwokacyjnym 1733 r. W: Między Zachodem a Wschodem. Studia ku czci profesora Jacka Staszewskiego. T. 2. Red. J. DumAnowsKI. Toruń 2003, s. 561-573.

Urzędnicy centralni i nadworni Polski XIV-XVIII wieku. Spis. Red. A. GąsıorowsKi. Kórnik 1992. Volumina Legum. T. 6. Wyd. J. Ohryzko. Petersburg 1860.

Wojciechowski B.: Ignacy Przyjemski, starosta łomżyński. Polityk lokalny czasów saskich. Olsztyn 2004.

Z Warszawy d. 12 Martii 1733. W: Od Augusta Mocnego do Augusta III. Doniesienia $z$ Warszawy Andrzeja Cichockiego z lat 1732-1734. Wyd. J. DygdAŁA. Warszawa 2016.

Adam Lisek

\section{Political postulates of the Mazovian Voivodeship noblemen during pre-convocation dietines in the year 1733}

Summary

As a result of Augustus II's sudden death, the Polish-Lithuanian Commonwealth went through the country's penultimate interregnum period, which instigated the fight for the Polish throne. What served as this competition's primary arena were the Mazovian pre-convocation dietines in the year 1733. Animosity and competition occurred therein between the national camp supporting the candidacy of Stanisław Leszczyński and the backers of Saxon succession. During the said crisis prompted by the interregnum period, the demands of state reform also appeared in dietines, for instance, regarding the enlargement of armed forces. Eventually, 5 of the dietines supported Leszczyński ("the Piast"), 3 did not expressed their stance, and in case of 2 of them it is hard to estimate what was their decision regarding the exclusion of the foreigner. All in all, the nobility supported the candidacy of the Pole during the provincial dietine of Mazovia.

Key words: Stanisław Leszczyński, Mazovian Voivodeship, pre-convocation dietines, interregnum period 